\title{
Digital Free Trade Zone in Facilitating Small Medium Enterprises for Globalisation: A Perspective from Malaysia SMEs
}

\author{
Mui-Yin Chin ${ }^{1 *}$, Lee-Peng Foo ${ }^{1}$, Mohammad Falahat ${ }^{2}$ and Hon-Choong Chin ${ }^{2}$ \\ ${ }^{1}$ Tunku Abdul Rahman University College (TAR UC), Kuala Lumpur, Malaysia \\ ${ }^{2}$ Universiti Tunku Abdul Rahman University (UTAR), Sungai Long, Malaysia \\ *Corresponding author
}

\begin{abstract}
The establishment of Digital Free Trade Zone (DFTZ) in Malaysia is closely related to the Chinese e-commerce giant. It was an initiative to spearhead Malaysia's national e-Commerce strategic roadmap and empowering Small and Medium Enterprises (SMEs) to do crossborder commerce seamlessly. As such, this study aims to understand the perception of Malaysia SMEs towards DFTZ initiative and identify the hidden trepidation of Malaysia's SMEs towards the e-commerce platforms via focus group interview as per Grounded Theory procedures. The findings reveal that about $40 \%$ of the interviewees are pessimistic about DFTZ and did not comprehend the potential benefit beyond it. Meanwhile, apart from incompatible cost structure and digital infrastructure development, lack of knowledge of technical support and digital talent in innovative marketing strategies are among the main reasons the interviewees hesitate to move towards e-commerce platforms. Therefore, the authorities are urge to take several measures such as providing significant incentives for SMEs to upskilling their workforce, nurturing technology talent and ensuring the development of digital infrastructure to eliminate the trepidation that Malaysia SMEs currently faced. Be realistic and pragmatic when reviewing the capabilities of local SMEs against the factory of the world is utmost important in helping them to go global and remain competitive.
\end{abstract}

Keywords: DFTZ; Digital infrastructure; Go Global; Grounded Theory; Malaysia SMEs

\section{Introduction}

Digital Free Trade Zone (DFTZ) was an initiative to spearhead Malaysia's national eCommerce strategic roadmap (NeSR), and it was launched to intensify Malaysia's participation in cross border e-Commerce Ministry of International Trade and Industry (MITI) (2018). The main objective of this initiative is to establishing Malaysia as a regional and global e-Commerce fulfilment hub and to drive exports. It is about empowering entrepreneurs and small businesses to do cross-border commerce seamlessly, open up the 
doors to global markets and to simplify e-Commerce by digitalising the trade process (Lee, Falahat, and Sia 2019; Yean, 2018) without having physical branches overseas.

Malaysia Digital Economy Corporation (MDEC) (2020) reported that DFTZ has successfully helped 13,000 local Small and Medium Enterprises (SMEs) gaining access to regional and global e-Commerce markets at the end of 2019, growing from 2,000 local SMEs at the end of 2017. In addition, as per end of April 2018, 70 Malaysia SMEs had benefitted from the DFTZ and generated sales worth RM52.1 million with an export value of RM18.1 million (Kumar and Kaur, 2018). As the establishment of the DFTZ will facilitate SMEs to export their products globally, it is expected to create 60,000 jobs and double exports value of SMEs to RM162.9 billion by 2025 (Ministry of Finance, 2018).

Figure 1: SMEs on board DFTZ breakdown according to states in Malaysia

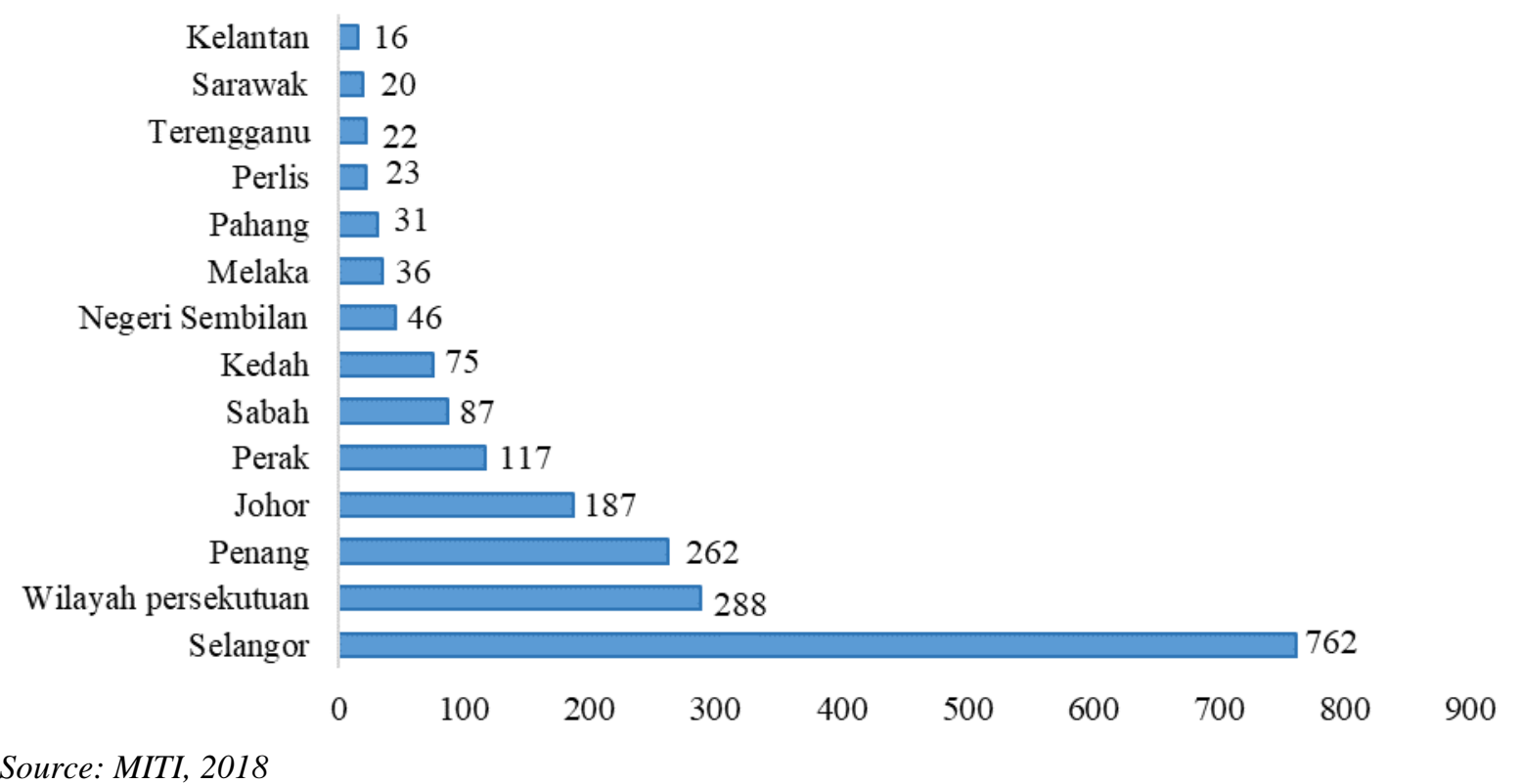

Source: MITI, 2018

From Figure 1, as per end of 2018, about 1,972 export-ready Malaysia SMEs were onboard the DFTZ. Of which, Selangor topped the list with the highest number of companies on board DFTZ, which is about $39 \%$. The number is consistent with the SME corporation report where the number of established SMEs within Malaysia was headed by Selangor (SME corporation, 2019). Whereas, Wilayah Persekutuan and Melaka ranked second and third in terms of number of SMEs participating in the DFTZ with 288 and 262 SMEs respectively.

DFTZ helps to enhance Malaysia SMEs competitive advantage, strengthen investors' confidence and to a large extent, build Malaysia's economic sustainability. However, how Malaysia SMEs can benefit from DFTZ remain unknown. Although the DFTZ seems promising local SMEs through greater market access, many economists have different perspectives. This is because DFTZ also open the door for greater access to the China market. In other words, the local consumers have direct access to the China market as well. When the local consumers heavily depending on the manufactured products brought from China, Malaysia importers, wholesalers, retailers, manufacturers and e-commerce SMEs will be badly disrupted due to lower-cost products and tax-free imports. It is definitely become an 
uneven playing field for local SMEs. As such, this study aims to understand the perception of Malaysia SMEs towards DFTZ initiative and identify the hidden trepidation of Malaysia's SMEs towards this e-commerce platform. In fact, Malaysia SMEs are always constrained by its small domestic market size, expanding their business at international level are seen as an alternative strategy to survive in this competitive environment. Taking a small business go global is a complex and dynamic process. Gaining a deep understanding of the targeted markets, the competition, current domestic market trends, and the requirements to successfully launch and drive growth lays an important foundation. Therefore, it is important to explore the readiness of domestic enterprises towards this initiative, especially when the information about the DFTZ is unseen mainly at the moment. As Malaysia SMEs consist of young and infant industry, hence, the outcome of this study is able to provide mode insights on awareness among Malaysia SMEs towards this initiative. In addition, the research findings will raise out the concern and hidden obstacles from Malaysia's perspective which will be shared among the public, including the Malaysian Government. Hence, the policy makers can design, share and implement effective policies to reap the benefits of DFTZ and enhance the sustainability of Malaysia SMEs.

\subsection{Organization of the study}

The remaining sections of this study are sorganised as follows: Section 2 describes the literature review; Section 3 illustrates the methodology used in this study; Section 4 discuss the empirical result; and the Section 5 concludes the study with policy implication.

\section{Literature Review}

\subsection{Background of DFTZ}

The establishment of Digital Free Trade Zone (DFTZ) in Malaysia is closely related to the Chinese e-commerce giant - Alibaba. It is the first electronic world trade platform outside China which can be regarded as the first step of the Digital Silk Road of China alongside with the Belt and Road Initiative (Brown, 2017). With the technology and platform support by Alibaba, Malaysia initiated its first DFTZ in November 2017. DFTZ comprises of three important components, which are eFulfilment hub, satellite service hub and eServices platform (MATRADE, 2016). The eFulfilment hub will benefit not only to Malaysia, but the whole ASEAN region as the establishment of eFulfilment hub will further develop the Kuala Lumpur International Airport (KLIA) Aeropolis into aviation, air cargo and the logistic hub that providing warehousing, logistics and streamlined customs clearance which is expected to shorten the time take for import and export activities (Ministry of Finance, 2018). Hence, the eFulfilment aims to transform Malaysia into a regional e-commence logistic hub that clear local delivery within 24 hours and worldwide delivery within 72 hours (Malaysia Airports Holdings Berhad, 2020).

On the other hand, located at the Kuala Lumpur Internet City (KLIC), the satellite services hub is moving forward to become a premier digital hub for both global and local internetrelated companies that are geared towards ASEAN markets (Ho, 2018). Accordingly, RM5 billion worth of KLIC development will accommodate 1,000 internet-related companies and 25,000 technology professionals at its 5 million square feet development site. Lastly, the eService platform is a virtual space development. This eService platform will complement to 
the first and second phase of DFTZ development by providing an integrated system that will connect the online services provided by e-commerce companies to the relevant Malaysia agencies. With this platform, it is expected that the custom clearance time will be reduced from 6 hours to 3 hours.

Alibaba will further enhance its investment in the second phase of DFTZ implementation via partnership between its logistic arm - Cainiao Network - with Malaysia Airports Holdings Berhad (MAHB) in a greenfield investment that is estimated to be operational in year 2020 . $70 \%$ of the stake will be held under the Cainiao Network and the remaining will belong to MAHB. A total of RM800 million investment is expected from the partnership in developing the eFulfilment hub at the Kuala Lumpur International Airport Aeropolis. The hub will eventually link to Alibaba electronic world trade platformed abovementioned to support the worldwide e-commerce trading. Altogether, DFTZ will provide a complete e-commerce ecosystem to the SMEs.

Essentially, the establishment of DFTZ is align with Malaysian National E-Commerce Strategic Roadmap. According to the roadmap, $80 \%$ of the local SMEs will likely to be drawn into e-commerce activity (MITI, 2016). With such a considerable amount of SMEs involvements, Malaysia economic growth is expected and will be driven by e-commerce activities (Miduon and Ismail, 2018). It is expected that e-commerce activity will contribute $6.4 \%$ (equivalent to an estimation of RM114 billion) to the nation's Gross Domestic Product (GDP) by year 2020 (MITI, 2016). This ambitious target can be achieved only with active participation of Malaysia SMEs in e-commerce activities, and, it can be further enhanced with the involvement of SMEs in DFTZ.

\subsection{Opportunities and Challenges for Malaysia SMEs go global}

Free trade zone is not a novel concept in facilitating SMEs in the global business environment, in fact, it has been established for decades. Nonetheless, in contrast to the traditional free trade zone that aimed to provide duty free for products and manufacturers to import and export goods, digital free trade zone serves special purpose whereby it facilitates trades between SMEs via electronic linkage (Midoun and Ismail, 2018). This electronic linkage required the SMEs to embrace the digital technology and adopt it for the trade activities - e-commerce. Adopting and adapting to this electronic linkage - digitalisation implies the participation of Malaysia SMEs in global market. This indicates an undeniable link between SMEs going global and e-commerce adoption (Lee and Falahat, 2019). In other words, one cannot discuss DFTZ without looking into the opportunities and challenges associated with global market. Alongside with the discussion of DFTZ implementation in Malaysia, it is, therefore, worth to acknowledge the opportunities and challenges faced by Malaysia SMEs in going to global.

Compilation of existing literature revealed that Malaysia SMEs are confronting with low productivity, lack of access to credit, limited business networks and inadequate managerial capabilities and company resources in the context of going global (Falahat, Ramayah, SotoAcosta, and Lee, 2020). Moreover, the slow recovery from an economic recession, shortage of human resource, difficulties in access to advanced skills and technology, inadequate government support, complex arrangement of trading and legal issues in global business environment, limited resource and planning for $R \& D$ activities, lack of awareness in 
intellectual property protection, as well as branding efforts are impeding Malaysia SMEs to enter global market (Falahat, Lee, Ramayah, and Soto-Acosta, 2020; Hashim, 2012; Richardson, 2014). On top of that, following the increasing exposure of local market to foreign counterparts (Sui and Baum, 2014), Malaysia SMEs is facing with intensified global challenges (Hassan and Sulaiman, 2016). This intensified global challenge has two facets: competing with foreign counterparts at their home market; and competing with local and foreign counterparts in Malaysia local context. With generally lack of resources, it is not surprised to learn that Malaysia SMEs will reluctant to enter global market but channeling their resources and focus on local market.

\section{Methodology}

\subsection{Theoretical Framework}

Bring a small business go global is a challenging task. However, to remain competitive and sustainable, go global is inevitable. Foreign Direct Investment (FDI) is one of the best ways to go global. In accordance with Dunning 's eclectic or Ownership, Locational, and Internalization (OLI) Advantages Theory, ownership-specific endowment, location-specific endowment, and sinternationalisation advantages and the three main factors of FDI (Dunning, 1980). Regardless of acquiring ownership, location or sinternalisation advantages, the motives of FDI are divided into four, namely, market seeking FDI, resource seeking, efficiency-seeking FDI and asset seeking FDI (Yu, Lee and Han, 2015). Out of which, market-seeking is the most relevant with Malaysia SMEs. Market seeking FDI create value to the enterprises mostly via downstream activities, for instance, marketing and sales ( $\mathrm{Yu}$, Lee and Han, 2015). However, enterprises would face various operational challenges in the host country (Anand and Delios, 1997) and incur very high cost as expanding business abroad is always difficult (Zaheer, 1995). Thus, a significant number of Malaysia SMEs might not be able to go global via market-seeking FDI.

Arising from the above, DFTZ becomes a pivotal method for Malaysia SMEs to go global if it is well accepted by the SMEs. Thus, this study adopts the Grounded theory to examine the selected respondents' perceptions towards DFTZ. Grounded theory is employed in this study as Finch (2002) revealed that the procedures of Grounded Theory provide insight to the researchers in developing additions to a discipline's theoretical knowledge which is matched with the objective of this study because this study aims to assess if DFTZ instead of FDI or other conventional methods would be an effective way in leading Malaysia SMEs to go global.

\section{Research Method}

Qualitative method is adopted in this study. This method best suited to achieve the objective of this study. Based on Chell 1988, p.52 cited by Brockman (2014), qualitative method is used as a useful tool in sorganisational analysis from within an interpretive.

The grounded theory highlights the diversity of data sources and obtained research data primarily via interviews. (Sun, et.al., 2020). In light of the above, the researchers developed a set of semi-structured interview questions which enabled the interviewees to provide detailed information (Akunna et.al., 2017). The questionnaire of this study is divided into 4 
sections. Section 1 aims to capture the demography of the interviewees. Meanwhile, Section 2 until Section 4 consist of open-ended questions, respectively. Section 2 focuses on the interviewees' perception towards DFTZ's initiative while Section 3 aims to derive the interviewees' view on the trepidation they face towards e-commerce platforms and the last section will delve in-depth the suggestions from interviewees.

The questionnaire is available at English and Chinese version. In order to make sure the content for both English and Chinse version are consistent, a back to back translation has been applied to the questionnaire. The back-translation was conducted by a bilingual editor; whose native language is English. The researchers will then compare the new translation with the original text and reconciling any meaningful differences between the two questionnaires. Thereafter, in accordance with the Grounded Theory, a semi-structured focus group interview is conducted with 15 selected SMEs from various states of Malaysia and various industries.

To select the appropriate interviewees, the researchers sutilise a relatively small pool of initial informants to access if they meet the eligibility criteria. In this study, three general criteria are set, firstly, the interviewees must be local SMEs; secondly, the location of the SMEs must fulfil the location requirements, i.e. 5 SMEs are located in Kuala Lumpur or Selangor followed by 3 from Penang, 2 from Melaka and Johor, respectively, and lastly one from Perak, Pahang and East Malaysia. The third criterion is that not more than three respondents are involved in the same industry. The information acquired via interview will then be interpreted using NVivo 11 Pro.

The NVivo 11 Pro is a powerful software tool to assist researchers from the time of sconceptualisation of a project through to its completion. Many past qualitative research papers using NVivo to derive the findings (see Musa, Kayak and Thirumoorthi, 2009; Brockman, 2014; Deptula, and Williams, 2017; Akunna et al., 2017; and Ronald, Daniel and Juan, 2018). This is due to the fact that NVivo is able to identify the meaning of the text, discover the patterns of the answers given by the respondents, identify themes, glean insights and upmost important is to produce robust findings for this study.

\section{Empirical Results and Discussion}

Table 1: The Demography of Focus Group Interviewees

\begin{tabular}{|c|c|c|c|}
\hline Stakeholder group & $\mathrm{N}=15$ & & \\
\hline Interviewee type (n) & Partnership (4) & Private limited (8) & Sole proprietor (3) \\
\hline Business location & $\begin{array}{l}\text { Penang (1) } \\
\text { Johor (1) } \\
\text { Pahang (1) } \\
\text { Perak (1) }\end{array}$ & $\begin{array}{l}\text { Kuala Lumpur (2) } \\
\text { Selangor (2) } \\
\text { Penang (2) } \\
\text { East Malaysia (1) } \\
\text { Malacca (1) }\end{array}$ & $\begin{array}{l}\text { Kuala Lumpur (1) } \\
\text { Malacca (1) } \\
\text { Johor (1) }\end{array}$ \\
\hline Year of operation & $\begin{array}{l}\text { Less than } 5 \text { years }(1) \\
6 \text { to } 10 \text { years }(1) \\
11 \text { to } 15 \text { years }(1) \\
16 \text { to } 20 \text { years }(1)\end{array}$ & $\begin{array}{l}\text { Less than } 5 \text { years }(1) \\
6 \text { to } 10 \text { years }(3) \\
11 \text { to } 15 \text { years }(2) \\
21 \text { to } 25 \text { years }(2)\end{array}$ & $\begin{array}{l}\text { Less than } 5 \text { years }(1) \\
6 \text { to } 10 \text { years }(1) \\
21 \text { to } 25 \text { years }(1)\end{array}$ \\
\hline
\end{tabular}




\begin{tabular}{|c|c|c|c|}
\hline Number of workers & $\begin{array}{l}\text { Less than } 5 \text { workers } \\
\text { (1) } \\
6 \text { to } 30 \text { workers (2) } \\
31 \text { to } 75 \text { workers (1) }\end{array}$ & $\begin{array}{l}\text { Less than } 5 \text { workers ( } 4 \text { ) } \\
6 \text { to } 30 \text { workers (4) }\end{array}$ & $\begin{array}{l}\text { Less than } 5 \text { workers }(1) \\
6 \text { to } 30 \text { workers }(2)\end{array}$ \\
\hline Business categories & $\begin{array}{l}\text { Food processing (2) } \\
\text { Electrical and } \\
\text { electronics (1) } \\
\text { Nonmetallic mineral } \\
\text { industry (1) }\end{array}$ & $\begin{array}{l}\text { Electrical \& electronics } \\
(2) \\
\text { Textiles \& Textiles } \\
\text { products (1) } \\
\text { Business services \& } \\
\text { supply (3) } \\
\text { Green technology (1) }\end{array}$ & $\begin{array}{l}\text { Food processing (1) } \\
\text { Machinery \& tools (2) }\end{array}$ \\
\hline Age of owners & $\begin{array}{l}\text { Less than } 30 \text { years old } \\
\text { (2) } \\
51-60 \text { years old (2) }\end{array}$ & $\begin{array}{l}\text { Less than } 30 \text { years old } \\
\text { (1) } \\
31 \text { to } 40 \text { years old (2) } \\
41 \text { to } 50 \text { years old (2) } \\
51 \text { to } 60 \text { years old (2) } \\
\text { Over } 60 \text { years old (1) }\end{array}$ & 31 to 40 years old ( 3 ) \\
\hline
\end{tabular}

Source: Authors' own compilation

Note: Number in parenthesis refers to the number of interviewees

The researchers held a total of two focus groups: One English session and one Chinese session (see Table 1) comprising of 15 SMEs. The interview processes for both sessions are deemed to be successful as all interviewees were very active. Both sessions were conducted via Google form to sminimise the personal touch due to covid-19 pandemic and aim to overcome scheduling conflicts. All data were collected between Jun 2020 and July 2020. Data from both focus group discussions were cleaned before it was imported to the NVivo.

\section{Perception towards DFTZ}

The findings showed that all of the interviewees claimed they are facing stiff competition from both domestic and foreign companies which hinder their resilience and competitiveness. Apart from competing with the existing well-established foreign companies, the intense competition also comes from large domestic companies where they often perform better than midsize and small companies. The scale and experience owned by the large companies clearly surpass the midsize and small companies. Hence, over $86 \%$ of the interviewees wish to expand their domestic market and explore international market. Meanwhile, $6 \%$ of them indicates that they have entered to the international market through partnership.

Besides that, $93 \%$ of the interviewees aware about the DFTZ initiative as it is spearheaded by Malaysia Digital Economy Corporation (MDEC) to create a business environment in Malaysia that enables local SMEs use e-Commerce platforms extensively for the cross-border trade instead of adopting outward FDI or other conventional method. However, many of them admitted that their understanding about the initiative remains at minimal. Hence, about $40 \%$ of the interviewees are pessimistic about the initiative and did not comprehend the potential benefit beyond the DFTZ. 


\section{The trepidation faced by SMEs towards e-commerce platforms}

The successful development and implementation of any e-commerce profitability strategy relies on two main areas: human capabilities and data (Saunila, Ukko and Rantala, 2018; Akter, and Fosso, Wamba, 2016). Lack of knowledge especially in term of technical support and digital talent in innovative marketing strategies are among the main reasons the interviewees hesitate and take a caution step when moving towards e-commerce platforms. Hence, mentoring, networking and exposing SMEs to the right talents can help to overcome the cultural norms that may limit their ability to confidently start or sustain projects in ecommerce and data-driven technology areas.

In addition, one of the concerns from the interviewees is the return on investment in ecommerce platform might not be compatible. Costs associated with drawing a customer into a store and into a website are markedly different. There is no best e-commerce platform in the market, as there are thousands of platforms with different e-commerce solutions. Consumer confidence is a key success for marketing a new product. However, almost $60 \%$ of the interviewees highlighted that lack of customer confidence in making faceless sales and prefer to pay cash on delivery has significantly delay or slower down the willingness of SMEs to spend on e-commerce platform.

Furthermore, the logistic company has long heralded the potential of e-commerce. Over years, the sector has seen many new players enter the market. However, over $67 \%$ of the interviewees opined that the current players are not competitive compared to other countries such as China. Most of them agreed that shipping delays are inevitable, however, often delay in the shipment definably ruined their business reputation. According to a survey by Parcel Perform and meta-search website iPrice Group, about $43 \%$ of consumers in Malaysia were unhappy with their e-commerce delivery experience, citing that Malaysia reports the longest transit time in the region, with deliveries taking 5.8 days versus a regional average time of 3.3 days (New Straits Time, 2019).

\section{Feedback and suggestion from the interviewees}

Majority of the interviewees agreed that upgrading themselves in terms of digital skills will be the most crucial element in their to-do list. Although e-commerce always being cited as cost-effective as the rental and maintenance fee can be waived. However, in order to retain the customer, a more aggressive move have to take in order to build a sense of trust between the business and customer.

Most interviewees are grateful with the government efforts on allocating RM2 billion fund to drive Malaysia's economy with the process of sdigitalising local businesses, SME's financing options and taxes rebate on re-sstrategising with new businesses and mergers of SMEs. Furthermore, the recently announced e-wallet rebate which is part of the larger National Economic Recovery Plan (Penjana) aimed at helping to revive the local economy, particularly the merchants under the small-medium enterprise (SME) group, as well as to rebuild the lives of all Malaysians following the impact of the Covid-19 pandemic are welcomed by SMEs as its spur domestic spending at local businesses and as a result, allow these enterprises to bounce back quickly. 


\section{Conclusion and Policy Implication}

The high mortality rate of SMEs is mainly due to its inability to survive in the dynamic business environment (Akunna et.al., 2017). Therefore, SMEs need to venture into global market in order to expand their market shares and remain competitive. At this juncture, it is believed that DFTZ could play a pivotal role in facilitating trades among SMEs via electronic linkage. Therefore, this study aims to identify the Malaysia SMEs perceptions and trepidation they face towards DFTZ via focus groups interview.

The findings of this study show that majority of the interviewees aware that the DFTZ initiative enables them to use e-commerce platforms for the cross-border trade, but about $40 \%$ of the interviewees are pessimistic about the initiative and did not comprehend the potential benefit beyond the DFTZ. Meanwhile, apart from incompatible cost structure and infrastructure development, lack of knowledge of technical support and digital talent in innovative marketing strategies are among the main reasons the interviewees hesitate to move towards e-commerce platforms.

To ensure the successfulness of DFTZ in helping and sustaining Malaysia SMEs business, it is crucial to change the perceptions of the SMEs by helping them to transform the challenges and trepidation into opportunities and challenges. First of all, the Malaysian Government should provide a significant incentive for SMEs to upskilling their workforce, particularly in terms of ICTliteracy . Besides, as per Punithaa Kylasapathy, Tan \& Ahmad Haris Mohd Zukki (2018) suggestions, a universal digital infrastructure is essential to motivate digital adoption and participation which in turns will reduce costs of services delivery and increase the competitiveness of Malaysia SMEs. In addition, effective regulations in the broadband market are crucial for a competitive market structure in enabling the provision of high-quality yet affordable digital infrastructure. This will increase the confidence of both SMEs and their customers, and further reduce the operation cost of SMEs.

Apart from the above, based on Malaysia Budget 2020, a new Digital Talent Development Strategy Framework, designed for end-to-end nurturing of Malaysia's technology talent is anticipated to address the high demand for a digital-savvy workforce (MDEC 2019) and to solve the Malaysia SMEs' problem in terms of shortage of digital talent.

All in all, the authorities need to ensure the development of digital infrastructure and talents as well as does not create an irreversible uneven playing field for local SMEs. Be realistic and pragmatic when reviewing the capabilities of local SMEs against the factory of the world is utmost important in helping to go global and remain competitive.

\section{Acknowledgement}

Financial supports from Tunku Abdul Rahman University College (TARUC) via internal research grant: UC/I/G2019-00036/R21001is gratefully acknowledged. 


\section{References}

Akter, S. \& Fosso, Wamba, S. (2016). Big Data Analytics in ECommerce: A Systematic Review and Agenda for Future Research, Electronic Markets, DOI 10.1007/s12525-0160219-0.

Akunna,Y, Duan, Y., Alhusan F. B. and Haag, M. (2017). Understanding the Influence of Social Capital on Knowledge Transfer in Nigeria SMEs Proceedings of the International Conference on Intellectual Capital, Knowledge Management \& Organizational Learning

Anand, J., \& Delios, A. (1997). Location Specificity and The Transferability of Downstream Assets to Foreign Subsidiaries. Journal of International Business Studies. vol 28(3), pp.579-603.Brockman, J.L. (2014). Interpersonal Conflict in Construction: Cost, Cause, and Consequence. Journal of Construction Engineering \& Management. Vol 140 (2), pp. 04013050-1- 04013050-2.

Brown, R. (2017). "Beijing's Silk Road goes Digital”. Available at https://www.cfr.org/blog/beijings-silk-roadgoes-digital <Accessed 21 April 2020>

Deptula, B. J. and Williams, E. A. (2017). An Intersubjective Perspective on the Role of Communal Sharing in Synergistic Co-mentoring: Implications for Human Resource Development. Human Resource Development Quarterly, vol. 28 (3), pp. 369-400.

Dunnimg, J. H. (1980) Toward an eclectic theory of international production Journal of International Business Studies, vol.22 (3), pp.1-3

Finch, J.H. ( 2002). The Role of Grounded Theory in Developing Economic Theory. Journal of Economic Methodology. Vol 9 (2), pp. 213-234.

Falahat, M., Ramayah, T., Soto-Acosta, P., \& Lee, Y. Y. (2020). SMEs internationalisation: The role of product innovation, market intelligence, pricing and marketing communication capabilities as drivers of SMEs' international performance. Technological Forecasting and Social Change, 152, 119908.

Falahat, M., Lee, Y. Y., Ramayah, T., \& Soto-Acosta, P. (2020). Modelling the effects of institutional support and international knowledge on competitive capabilities and international performance: Evidence from an emerging economy. Journal of International Management, 26, 100779.

Hashim, F. (2012). Challenges for the sinternationalisation of SMEs and the role of government: the case of Malaysia. Journal of International Business and Economy, 13, 97122.

Hassan, R.A. and Sulaiman, R.S. (2016). Social network and market orientation as the key factors in determining the success of small and medium enterprises (SMEs) in Malaysia. The International Journal of Business and Management, 4, 393-397.

Ho, S. (July 04, 2018). “Tech: KL Internet City looking for an alternative site”. The Edge Malaysia. Available at https://www.theedgemarkets.com/article/tech-kl-internet-citylooking-alternative-site <Accessed 3 May 2020>

https://www.thestar.com.my/business/business-news/2018/04/09/mustapa-70-smes-in-dftzscheme-generate-rm52m-sales 
Kumar \& Kaur (2018). DFTZ not dependent only on Alibaba. 27 July 2018. The Malaysian reserve. Available at https://themalaysianreserve.com/2018/07/27/dftz-not-dependent-onlyon-alibaba/

Malaysia External Trade Development Corporation (MATRADE). (2016). "Digital Free Trade Zone (DFTZ)”. Available at http://www.matrade.gov.my/en/digital-free-trade-zone$\underline{\mathrm{dftz}}<$ Accessed 3 May 2020>

Malaysia Airports Holdings Berhad (2020), Malaysia Airports and Alibaba Annouce Operation Commencement of Cainiao Aeropolis eWTP Hub, Malaysia. 3 November 2020. Malaysia Airports Holdings Berhad. Available at https://www.malaysiaairports.com.my/media-centre/news/malaysia-airports-and-alibabaannounce-operation-commencement-cainiao-aeropolis

Lee, Y. Y., Falahat, M., \& Sia, B. K. (2019). Impact of Digitalization on the Speed of Internationalisation. International Business Research, 12(4), 1-11.

Lee, Y. Y., \& Falahat, M. (2019). The Impact of Digitalization and Resources on Gaining Competitive Advantage in International Markets: Mediating Role of Marketing, Innovation and Learning Capabilities. Technology Innovation Management Review, 9(11).

MDEC (2019). National Budget 2020: 12 Reasons Why Malaysia is The Referred Digital Investment Location. Available at https://mdec.my/blog/?p=283.

Midoun, S. and Ismail, B. (2018). Digital and Free Trade Zones Impact on Malaysia's Economy and Its Prospects (2000-2018). International Journal of Economics and Financial 8(4), 39-44.

Ministry of Finance (2018). Economic report 2017/2018. Available at https://www1.treasury.gov.my/pdf/economy/er/1718/chapter1.pdf

Ministry of Finance. (2017). Budget 2018. Putrajaya: Ministry of Finance.

Ministry of Finance. (2018). Economic Outlook 2019. Putrajaya: Ministry of Finance

Ministry of International Trade and Industry (MITI). (2016). "National eCommerce Strategic Roadmap Overview". Available https://www.miti.gov.my/miti/resources/Gallery_Walk.pdf <Accessed 3 May 2020>

MITI (2018). Malaysia International Trade and Industry report 2018. Available at https://www.miti.gov.my/miti/resources/MITI\%20Report/MITI_Report_2018.pdf

Musa, G., Kayak, K. and Thirumoorthi, T. (2009). The experiential aspect of rural home-stay

Nath, H.K. and Liu, L. (2017). Information and communications technology (ICT) and services trade. Information Economics and Policy, 41, 81-87

New Straits Times. (2019). Malaysians not happy with e-commerce delivery experience: Study. Bernama. June 26, 2019.

Punithaa Kylasapathy, Tan, BH. And Ahmad Haris Mohd Zukki (2018) Unlocking Malaysia's Digital Future: Opportunities, Challenges and Policy Responses, Bank Negara Malaysia. Available at 


\section{IIMIIECONF}

4th International Conference On Research In

ttps://www.bnm.gov.my/index.php?ch=en_publication\&pg=en_work_papers\&ac $=59 \& b b=f$ ile

Richardson, C. (2014). Firm internationalisation within the Muslim world. Journal of World Business, 49(3), 386-395 